\title{
PERAN ORANGTUA PENAMBANG EMAS DALAM MENANAMKAN PENDIDIKAN AGAMA ISLAM PADA ANAK DIKELURAHAN KAMPUNG JAWA
}

\section{Wilyam Afsiska, Beni Azwar, Cikdin, Asri Karolina, Eka Yanuarti}

Institut Agama Islam Negeri, Curup, Indonesia afsiska.wilyam06@gmail.com, beniazwar@iaincurup.ac.id, cikdin@iaincurup.ac.id, asrikarolina@iaincurup.ac.id, ekayanuarti@iaincurup.ac.id

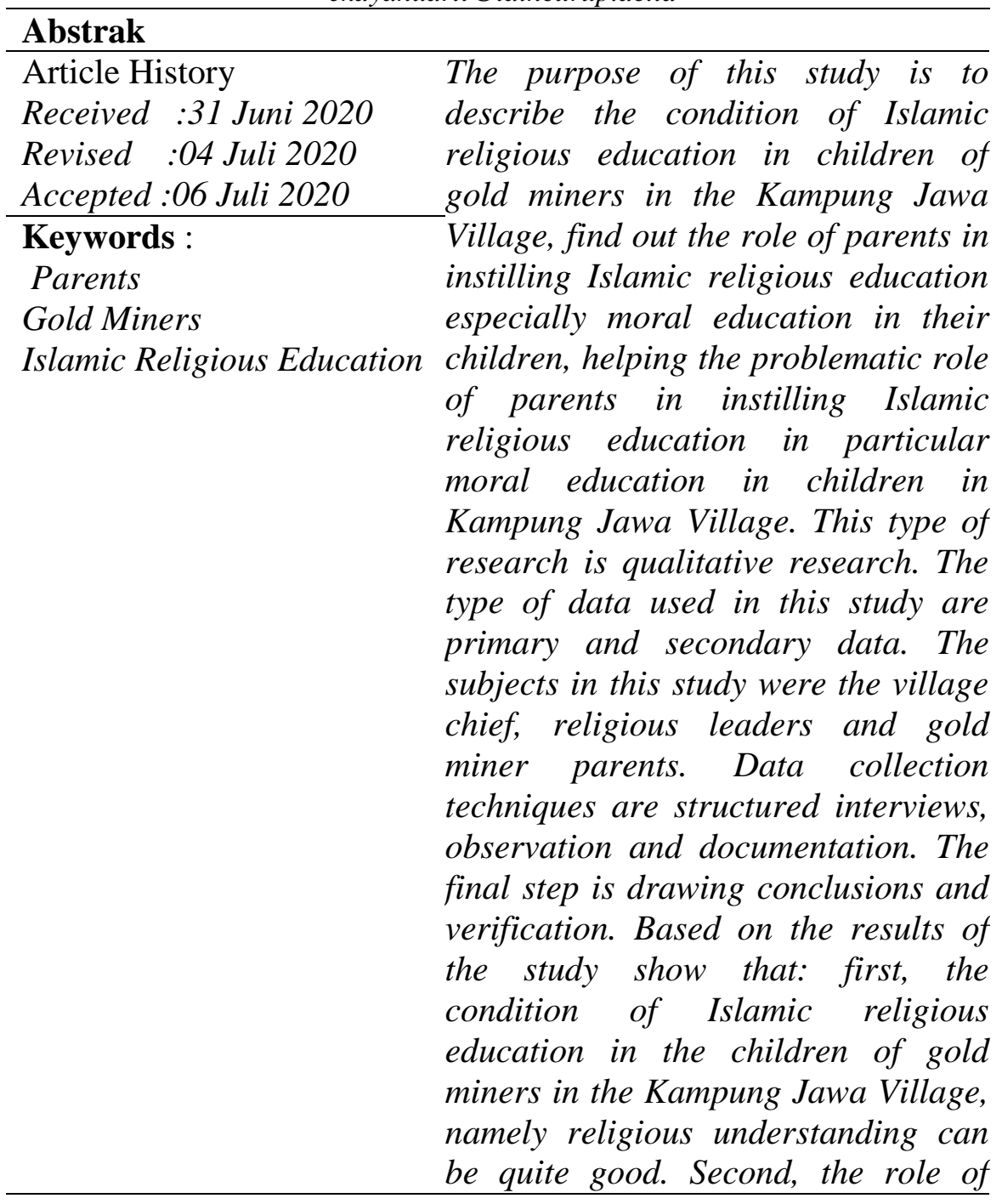




parents of gold miners in instilling
moral education to their children
varies depending on the
understanding of parental religious
knowledge. Third, the probelmatic
role of parents consists of internal
factors that are constrained by
parents who are busy working that
make children less controlled to
behave properly according to Islamic
teachings, external factors that are
constrained by children unruly and
difficult to be advised.

\section{Pendahuluan}

Peran orangtua dalam pendidikan anak akan berpengaruh positif apabila orangtua benar-benar memahami keterlibatan dalam pendidikan anak-anaknya, terutama dalam pendidikan agama islam. Hal ini agar orangtua dapat memutuskan tindakan yang tepat dalam pendidikan agama pada anak. Seorang anak merupakan aset yang berharga bahkan bisa membantu menyelamatkan kehidupan orangtuanya baik didunia maupun diakhirat. Orangtua harus membimbing serta mendidik anak-anaknya dengan pemahaman pendidikan agama islam serta orangtua dapat memberikan tauladan yang baik kepada anaknya karena anak-anak mudah meniru apa yang orangtua lakukan atau bicarakan. Bahwa keterlibatan orangtua merupakan hal yang sangat penting untuk mendukung pendidikan agama Islam pada anak (Rahminur, 2016: 61-71).

Pendidikan merupakan sebuah kunci keberhasilan generasigenerasi yang memiliki sifat beradab. Tanpa adanya pendidikan suatu bangsa dan negara ini tidak akan bisa berkembang. Dibelahan dunia ini, bahkan daerah yang jauh dari pendidikan bisa dikatakan jauh dari nuangsa keberadapan, bahkan bisa dikatakan kurang beradap. Apalagi yang tidak pernah kenal dengan pendidikan, yang sudah mengenali pendidikan saja masih ada yang jauh dari kata beradab. Arti penting dari kata pendidikan, yang membuat manusia semakin beradab. Oleh sebab itu pendidikan harus dimulai dari sedini mungkin. (Karolina, 2019)

Untuk memiliki suatu pendidikan agar seorang anak mengetahui 
suatu hal yang baik dan hal yang buruk, pendidikan orangtua sangat diperlukan untuk memberikan pendidikan agama kepada anakanaknya. Keterlibatan orangtua dalam pendidikan agama islam pada anak tidak dapat berjalan begitu saja. Usaha yang harus dilakukan oleh keluarga, hendaklah ayah dan ibu memberikan pengetahuan tentang ilmu agama terutama agama islam agar anak dalam melakukan atau bertindak selalu mengikuti syariat yang diajarkan dalam islam, baik itu tingkah lakunya, karakternya dan lain sebagainya (Hyoscyamina, 2011)

Setiap anak harus dipertanggungjawabkan oleh keluarganya dalam segala hal apapun terutama dalam pendidikan agama islamnya. Dalam kehidupan mereka akan bertemu dan mendapatkan pengalaman, baik itu dari lingkungan sekolah maupun lingkungan masyarakat (Mulia, 2019). Sehingga apabila anak tersebut tidak dibentengi dengan pendidikan agama islam oleh orangtuanya maupun keluarganya, maka mereka dapat terbawa oleh hal-hal yang dilarang oleh syariat agamanya. Pendidikan agama islam berarti suatu usaha atau proses yang dilakukan untuk menanamkan keimanan pada diri anak agar menjadi anak yang memiliki kepribadian muslim yang taat beribadah kepada Allah SWT serta dapat mengamalkan seluruh ajaran agamanya dalam kehidupan sehari-hari (Sudiyono, 2009: 5).

Mengajarkan pendidikan agama islam pada anak sudah menjadi tugas dari keluarga, khususnya bagi orangtua. Menanamkan pendidikan agama islam kepada anak merupakan tujuan dari pendidikan agar mereka dapat hidup rukun dan selalu menjunjung tinggi nilai toleransi kepada siapa saja. Menjadi seorang orangtua bagi anak-anak, tidaklah dengan melahirkan saja akan tetapi menjadi seorang ayah dan ibu apabila mereka membimbing serta mendidik seorang anak mereka dengan pendidikan yang selayaknya mereka dapati terutama pendidikan Islam.

Peranan orangtua sangatlah penting didalam membentuk sikap dan norma-norma hidup bertetangga dan bermasyarakat, pengembangan bakat dan minat serta pembinaan bakat dan kepribadian. Hal tersebut telah dijelaskan oleh Singgih D. Gunarsa yaitu : "Hubungan antara individu per individu didalam keluarga sangat dipengaruhi oleh orangtua yaitu ayah dan ibu didalam sebuah perspektif bahkan arah pendidikan yang akan mendamaikan Susana didalam sebuah keluarga. Masing-masing seorang individu didalam sebuah keluarga agar dapat memehami peranannya didalam keluarga 
tersebut. Karena didalam keluarga merupakan wadah untuk perkembangan. Jadi, orangtua mempunyai peranan yang sangat penting didalam tugas dan tanggung jawabnya yang besar kepada semua anggota didalam sebuah keluarga tersebut (Gunarsa, 1995: 8).

Orangtua sebaiknya tidak meninggalkan anak mereka dalam keadaan lemah. Karena lemah disini maksudnya adalah lemah dalam segala aspek kehidupan seperti lemah mental, psikis, pendidikan, ekonomi terutama lemah didalam imam (spiritual). Anak yang lemah iman akan menjadi generasi tanpa kepribadian. Jadi, orangtua harus memperhatikan segala aspek perkembangan anak baik dari segi perhatian, kasih sayang, pendidikan mental ataupun masalah aqiqah atau keimanannya. Maka bertqwalah kepada Allah para orangtua, berlaku lemah-lembutlah kepada anak, karena dengan berperilaku lemah-lembut sangat membantu dalam menanamkan pendidikan agama pada anak, karena baik buruknya anak, tergantung bagaimana cara orangtua dalam mendidik dan membesarkannya.

Bahkan untuk memperkuat pribadi, meneguhkan hubungan sesame, memperdalam rasa syukur kepada Allah atas nikmat dan perlindungan yang selalu kita terima, maka dirikanlah shalat, karena melalui dengan shalat kita dapat melatih lidah, hati dan seluruh anggota badan untuk selalu ingat kepada Allah SWT.

Pendidikan didalam sebuah keluarga adalah pendidikan yang paling utama, dimana orangtua yang paling bertanggung jawab terhadap perkembangan anaknya. Kaidah ini ditetapkan, karena mereka ditakdirkan menjadi orangtua anak yang dilahirkan. Pendidikan didalam rumah tangga bertujuan agar seorang anak mampu mengemabangkan atau memahami secara menyeluruh potensi manuasiwinya yaitu jasmani dan akal dan rohani. Kunci pendidikan didalam sebuah keluarga itu yaitu pendidikan rohani (kalbu) atau pendidikan agama. Hal ini dikarenakan pendidikan agama paling berperan besar terhadap pandangan perubahan hidup seseorang (Fitri, 2016).

Berdasarkan survei awal yang telah dilakukan peneliti di Kelurahan Kampung Jawa, penulis memandang bahwa saat ini begitu banyak orangtua yang belum menanamkan pendidikan agama islam pada anak-anaknya, karena orangtua kurang memiliki dasar pengetahuan agama yang baik, orangtua yang kurang mempedulikan perkembangan anaknya sehingga tidak mengerti akan kebutuhannya, orangtua yang sibuk dan bekerja sebagai penambang emas untuk 
memenuhi kebutuhan materi anak-anaknya, waktu yang ada dihabiskan di luar rumah, bahkan di luar kota yang jauh dari keluarga. Orangtua penambang emas ini banyak mengorbankan waktu untuk bekerja, karena penambang akan lebih fokus dan lebih aktif ditempat tambang, tidak sempat mengawasi perkembangan anaknya, bahkan tidak punya waktu untuk memberikan bimbingan, sehingga pendidikan bagi anak-anaknya terabaikan.

Hasil wawancara kepada warga Kelurahan Kampung Jawa, beliau mengatakan bahwa "Disini pendidikan agama islam pada anakanak yang orang tuanya bekerja sebagai penambang emas memang kurang bagus bahkan ada anak yang memang sangat jauh dari akhlak yang baik, seperti halnya sering mengeluarkan kata-kata yang tidak baik, anak-anak juga sering berkelahi. Namun hal tersebut tidak bisa disalahkan pada anak karena anak juga membutuhkan nasihat, teguran dan ajaran dari orangtuanya terutama ajaran agama islam. Dan mayoritas orangtua disini memiliki pekerjaan sebagai penambang emas, mereka banyak menghabiskan hari dan waktu dipekerjaan mereka sebagai penambang emas. Jadi mereka tidak sempat untuk membina akhlak anak mereka secara langsung" (Wawancara, 2019).

Adapun penelitian sebelumnya yang mengangkat persoalan peran orangtua dalam menanamkan pendidikan agama islam, penelitian yang dimaksud yaitu Peran Orang Tua Dalam Pembinaan Nilai-Nilai Keagamaan Pada Anak Di Desa Lambusa Kec. Konda Kabupaten Konawe Selatan. Hasilnya bahwa orang tua berperan penting dalam pembinaan nilai-nilai keagamaan pada anak. Nilai-nilai keagamaan yang diajarkan orang tua pada anak di Desa Lambusa Kec. Konda Kab. Konawe Selatan adalah nilai-nilai keimanan, peletakkan dasar-dasar keperibadian, dan pembentukan kesadaran beribadah. Dalam hal ini dapat dilihat untuk membina anak agar mempunyai sifat-sifat terpuji, tidaklah mungkin dengan penjelasan pengertian saja, akan tetapi perlu membiasakannya untuk melakukan yang baik, yang diharapkan nanti dia akan memiliki sifat -sifat tersebut dan menjauhi sifat-sifat tercela. Kebiasaan dan latihan-latihan itulah yang membuat dia cenderung kepada melakukan yang baik dan meninggalkan yang kurang baik. Seharusnya para orangtualah yang berperan memberikan pendidikan tentang agama kepada anakanaknya agar anak-anaknya secara tidak langsung mengerti pendidikan tentang agama dari hal yang dasar terlebih dahulu. Dari sinilah bahwa terbukti ada permasalahan mengenai peran orangtua 
penambang emas dalam mendidik anak tentang pendidikan agama Islam.

Tujuan dalam penelitian ini adalah sebagai berikut :

a. Untuk mengetahui peran orangtua penambang emas didalam menanamkan pendidikan agama islam pada anak di Kelurahan Kampung Jawa Kecamatan Lebong Utara.

b. Untuk mengetahui kondisi pendidikan agama islam pada anak penambang emas di Keluruhan Kampung Jawa

c. Untuk mengetahui peran orangtua agar dapat menanamkan pendidikan agama islam khususnya pendidikan akhlak pada anaknya.

d. Untuk mengetahui problematika peran orangtua dalam menanamkan pendidikan agama islam khususnya pendidikan akhlak pada anak di Kelurahan Kampung Jawa.

Manfaat yang ingin dicapai dari penelitian ini adalah sebagai berikut :

a. Secara Teoritis, hasil dari penelitian ini diharapkan dapat memberi masukan dalam pengembangan ilmu pengetahuan khususnya aspek apa saja dari pendidikan agama yang ditanamkan pada diri anak, serta diharapkan dari hasil penelitian ini khususnya bagi penulis dan pembaca dapat menambah wawasan, seperti bagaimana peran orangtua penambang emas dalam menanamkan pendidikan agama islam pada anaknya.

b. Secara Praktis, hasil penelitian ini diharapkan dapat bermanfaat:

1. Bagi penulis, untuk melatih dan mengembangkan kemampuan dalam bidang penelitian, serta dapat menambah wawasan pengetahuan penulis tentang peran orangtua penambang emas dalam menanamkan pendidikan agama islam pada anak.

2. Bagi keluarga, hasil penelitian ini diharapkan dapat memberikan bimbingan serta masukan yang baik terhadap orangtua agar menanamkan pendidikan kepada anak.

3. Bagi masyarakat, hasil penelitian ini diharapkan dapat memberikan pengetahuan kepada masyarakat bagaimana cara yang baik dalam menanamkan pendidikan agama islam pada anak.

\section{Metode Penelitian}

Jenis Penelitian 
Penelitian ini merupakan jenis penelitian yang dilakukan adalah penelitian kualitatif, yaitu penelitian yang digunakan untuk meneliti pada kondisi objek yang alamiah, di mana peneliti adalah sebagai instrument kunci, data yang didapat akan dilakukan dengan teknik penggumpulan data secara penggabungan data serta hasil penelitian kualitatif lebih menekankan makna daripada generalisasi (Sugiyono, 2014: 1).

\section{Sumber Data}

Sumber data yang dimaksud dalam penelitian ini yaitu data primer dan data sekunder. Data primer melalui hasil wawancara data yang peneliti peroleh dari hasil wawancara dengan subyek, responden, informan dan hasil observasi terkait peran orang tua penambang emas dalam menanamkan pendidikan agama islam pada anak. Sedangkan data sekunder yaitu dokumen-dokumen yang berkaitan dan mendukung, seperti buku-buku, jurnal dan yang mendukung lainnya (Sudaryono, 2016: 62).

\section{Prosedur}

Pendekatan yang digunakan yaitu pendekatan deskriptif. Dalam pendekatan deskriptif, data yang dikumpulkan adalah berupa kata-kata, gambar, hasil pengamatan, hasil wawancara, pemotretan, cuplikan tertulis dari dokumen, catatan lapangan, disusun dilokasi penelitian tidak dituangkan dalam bentuk bilangan statistik (Sudjana, 2004: 197).

\section{Teknik Pengumpulan Data}

a. Observasi

Observasi ini dilakukan melalui pengamatan secara langsung menuju objek penelitian untuk melihat dari dekat kegiatan yang dilakukan. pemusatan perhatian terhadap suatu objek dengan menggunakan seluruh panca indra. Observasi dilakukan untuk mendapatkan data dan informasi yang diperlukan dan dikumpulkan melalui pengamatan langsung di tempat penelitian (Riduwan, 2012: 76)

b. Wawancara

Wawancara ini digunakan bila ingin mengetahui hal-hal dari responden secara lebih mendalam serta jumlah responden sedikit. 
Ada beberapa factor yang akan mempengaruhi wawancara dan situasi wawancara (Riduwan 2012: 74)

c. Dokumentasi

Dokumen-dokumen yang telah dihimpun terlebih dahulu dipilih yang sesuai dengan tujuan dan fokus masalah yang akan diteliti. Metode ini digunakan untuk mencari data mengenai hal-hal yang dapat dijadikan sebagai bahan informasi untuk melengkapi data-data peneliti. Dalam hal ini peneliti akan meminta pada kelurahan mengenai sejarah, dokumen lain yang diperlukan (Syarnubi, 2016: 136)

\section{Teknik Analisis Data}

Teknik analisis data yang digunakan dalam penelitian ini adalah analisis data kualitatif model interaktif dari Miles dan Huberman yang meliputi data reduction, data display, dan conclusion drawing/verification (Sugiyono, 2014: 15)

\section{Pembahasan}

Berdasarkan hasil obsevasi, wawancara dan dokumen dari tokoh agama di kelurahan kampung jawa serta orangtua penambang emas mengenai peran orangtua penambang emas dalam menanamkan pendidikan agama islam pada anak di Kelurahan Kampung Jawa.

\section{Kondisi Pendidikan Agama Islam Pada Anak Penambang Emas Di Keluruhan Kampung Jawa}

Untuk mendapatkan gambaran atau pemahaman tentang keagamaan anak-anak di Kelurahan Kampung Jawa yang orangtuanya bekerja sebagai penambang emas. Dominan di kelurahan kampung jawa ini, masyrakatnya bekerja sebagai penambang emas dikarena memungkinkan keuangan ataupun pekerjaan yang mudah didapatkan, pekerjaan ini juga bisa dikerjakan oleh siapa saja dari anak-anak remaja, dewasa dan juga karena sebagian masyarakatnya yang kurang memiliki pendidikan untuk melakukan pekerjaan yang lebih ringan. Pekerjaan yang dilakukan oleh orang tua yang akan menghabiskan waktu seharian atau bahkan lebih dari sehari, ada juga yang bekerja lebih dari seminggu bahkan sebulan dikarenakan tempat menambang emas yang sedikit jauh dari rumahnya.

Menurut hasil wawancara dengan Umi Sujiarti yaitu, "bahwa 
pemahaman anak-anak penambang emas mengenai keagamaan sudah cukup terpenuhi walaupun orang tuanya sibuk bekerja sebagai penambang emas. Pemahanaman anak-anak penambang emas didesa ini sudah sedikit terpenuhi karena telah adanya kegiatan mengaji setiap sore di mushalla / di masjid ataupun kegiatan keagamaan yang lainnya sudah perlahan aktif seperti rohis, didikan subuh seminggu sekali serta sekarang telah didirikan sekolah baru yaitu SD IT serta TK IT yang untuk menunjang pengetahuan anak-anak mengenai agama lebih jauh akan tetapi terkadang terkadang kendala dengan anak-anaknya yang kurang berpartisipasi didalam kegiatan keagamaan tersebut" (Wawancara, 29 Desember 2019).

Sama halnya dengan perkataan dari Bapak Samsir, bahwa : "Selain sebagai Imam Mushalla, saya juga mengajar ngaji anak-anak didesa kelurahan kampung jawa ini, selama saya mengajar ngaji dari rumah ke rumah bahkan ngajar ngaji setelah magrib untuk anak-anak disini. Dari yang saya lihat, anak-anak dari orangtua penambang emas ini pemahaman keagamaannya sudah baik karena mereka sering mengikuti didikan subuh dan kegiatan keagamaan di mushalla atau dimasjid, mereka juga kalau dengan saya nurut atau saat dikasih tahu mereka mengerti dan mengikuti perkataan saya. Akan tetapi saya tidak mengetahui perilaku mereka didepan orangtuanya" (Wawancara, 1 Maret 2020)

Dari wawancara dengan perangkat agama di Kelurahan Kampung Jawa tersebut maka dapat disimpulkan bahwa pemahaman agama anak-anaknya cukup mengenal akan agama dari kegiatan keagamaan yang di adakan di Kelurahan Kampung Jawa, dan juga dengan adanya sekolah-sekolah agama maka akan menjadi penunjang anak-anak untuk mendapatkan pemahaman ilmu agama, walaupun orangtua mereka kurang memberikan pengetahuan mengenai ilmu agama.

Dikalangan kelurahan kampong jawa ini mayoritas beragama islam dan mengetahui tentang agama. Anak-anak yang orangtuanya bekerja sebagai penambang emas merupakan anak-anak yang beragama islam. Berdasarkan pemahaman keagamaan anak-anak di kelurahan kampung jawa, pemahaman keagamaannya bisa dikatakan lumayan untuk anak-anaknya walaupun dominan orang tua nya kurang mengerti mengenai perintah agama. Akan tetapi orang tuanya tetap mengajarkan pengetahuan pendidikan agama islam pada anakanaknya sesuai pengetahuan orang tuanya, karena orang tuanya lebih 
memfokuskan anak-anak ke sekolah dan pengajian. Jadi orang tuanya tidak khawatir mengenai hal tersebut. Ternyata sekarang telah adanya pengajian untuk orang tua, hal tersebut dilakukan agar anak-anak lebih mendalami dan menguasai ilmu pendidikan keagamaan, orangtua juga mengharapkan agar dari pendidikan pengajian ini, ia dapat mengajarkan atau membimbing serta mengarahkan anakanaknya kedalam didikan yang baik serta anak-anaknya dapat berprilaku yang baik dan meninggalkan perilaku yang buruk.

\section{Peran Orangtua Dalam Menanamkan Pendidikan Agama Islam Khususnya Pendidikan Akhlak Pada Anaknya}

Di era modern ini, pasti banyak permasalahan yang dialami oleh manusia terkhususnya untuk seorang anak. Pada fase ini anak-anak masih dalam keadaan pembawaan jasmani dan rohani sedang mengalami pertumbuhan yang menuju kematangan atau yang sering kita dengar dengan sebutkan fase transisi dari masa kana-kana menuju masa remaja. Sebelum anak-anak menuju masa dewasa, maka hendaknya anak-anak telah mempunyai bekal yang mendalam mengenai pendidikan keagamaannya. Oleh karena itu, orangtua merupakan pendidik utama dan pertama bagi anak-anaknya, karena dari merekalah seorang anak mula-mula menerima pendidikan. Orang tua atau ibu dan ayah memegang peranan yang penting dan amat berpengaruh atas pendidikan anak-anaknya, terutama pendidikan keagamaan bagi anak-anaknya.

Berdasarkan hasil wawancara yang peneliti lakukan dengan orang tua penambang emas yaitu bapak Novi. "Ada beberapa sarana yang saya berikan untuk menanamkan pendidikan agama pada anak, seperti poster shalat, huruf hijaiyah, cara berwudhu. Kegiatan keagamaan dimasyarakat cukup baik, melihat dari pengetahuan keagamaan anak-anak sedikit meningkat. Walaupun saya sibuk dalam bekerja akan tetapi saya memberikan sedikit pengajaran kepada anakanak ketika saya dirumah. Cara atau kiat saya memberikan pendidikan keagamaan kepada anak terutama pedidikan akhlak yaitu saya sering mencontohkan yang baik, seperti mengajak anak shalat, mengajarkan doa sebelum makan, doa sebelum/sesudah tidur dan doa sehari-hari lainnya. Saya sudah membiasakan anak-anak untuk berpuasa, mengaji dan bahkan telah mengajak anak-anak secara perlahan untuk mengerjakan shalat, akan tetapi saya belum menuntut agar anak-anak melakukannya, jika anak-anak belum mau. saya tidak 
memaksanya. Saya juga memberikan contoh kepada anak-anak yaitu menunduk jika berjalan didepan orang tua, ucapan terimakasih jika dibantu atau diberi sesuatu dari orang lain, meminta maaf jika berbuat salah" (Wawancara, 30 Desember 2019)

Penanaman pendidikan keagamaan kepada anak-anak sejak ia masih kecil merupakan kewajiban mutlak orang tua mengajari anak mengenai keagamaan untuk menjalani kehidupan dunia dan akhirat. Pendidikan keagamaan anak-anak tersebut dapat dijadikan pondasi agar mereka tidak keluar dari ajaran-ajaran agama. Kebanyakan anakanak yang orangtuanya bekerja sebagai penambang emas di kelurahan kampug jawa ini, mendapatkan ilmu agama dari sekolah dan juga dari guru ngajinya masing-masing. Sesuai dengan wawancara yang diungkapkan oleh bapak Wen Doni yang bekerja sebagai penambang emas, yaitu : "Sarana atau prasarana yang saya berikan untuk anakanak saya hanya tertuju dari sekolahan seperti buku pendidikan agama Islam dari sekolah. Ataupun prasarana nya yaitu mushalla, masjid yang ada di desa ini. Saya mengajari anak agar bersopan santun dan menghormati orang tua. Jika ada kegiatan dimasyarakat seperti pengajian, rohis, risma, saya menyuruh anak-anak untuk mengikutinya. Agar anak terhindar dari perilaku buruk maka usaha saya mendidik anak dengan mengajarkan memilih pergaulan yang baik. Jika anak saya berbuat salah maka saya lebih memilih untuk menasehatinya dari pada memukulinya" (Wawancara, 1 Januari 2020) Tak bisa dipungkiri, setiap anak pasti akan melakukan kesalahan dalam hidupnya. Dan pada umumnya, orangtuanya lah yang akan memarahi atau menegur anak mereka agar tak lagi melakukan kesalahan, hal tersebut itulah yang merupakan pemahaman orangtua terhadap anaknya yang nakal. Hal serupa juga disampaikan oleh bapak Hempiyu Hendro, bahwa : "karena kesibukan saya seharian diluar rumah jadi saya kurang mengetahui aktifitas dari anak-anak, tapi ketika saya berada dirumah maka saya memberikan sedikit pengajaran agama dan sopan santun yang baik kepada anak saya seperti mengingatkan anak-anak shalat, mengaji dan juga menegur jika anak-anak berkelahi dengan saudaranya dan mengeluarkan katakata yang kurang baik didengar. Walaupun saya kurang mengerti akan tentang keagamaan tetapi saya tetap memberikan pendidikan agama kepada anak melalui menyekolahkan anak, serta menitipkan ketempat mengaji” (Wawancara, 1 Januari 2020)

Orangtua harus selalu mengingatkan anak-anaknya agar tidak 
melakukan atau berperilaku yang buruk (tercela). Karena tuga orangtua lah yang harus mendidik anaknya agar terhindar dari hal yang buruk. Perilaku tercela merupakan perilaku yang harus dihindari karena perilaku tercela hanya akan memberikan dampak negatif bagi orang yang mengamalkannya dan makhluk sekitar. Dampak negatif tersebut daapat dirasakan langsung ketika hidup di dunia dan ada juga yang akan dirasakan ketika di alam akhirat kelak. Sebagaimana dengan yang disampaikan oleh bapak Primer yaitu : "saya memang jarang dirumah karena saya bekerja dari pagi hingga sore hari, akan tetapi saya selalu mengingatkan kepada anak agar jangan mengikuti teman-teman yang kurang baik, jangan sering berkelahi, dan juga jangan melawan kepada orang tua. Saya juga mengingatkan waktu shalat tiba jika saya dirumah, dan menyuruh anak saya untuk pergi mengaji setiap sore hari dimushalla. Anak saya memang bersekolah di umum tapi pembelajaran agamanya pasti dipelajari disekolah juga" (Wawancara, 1 Januari 2020)

Sama halnya yang disampaikan oleh bapak Ujang Hermanto, yaitu : "saya sendiri belum begitu pandai dalam melaksanakan perintah agama karena saya lebih focus ke pekerjaan dari pada mempelajari agama. Apalagi saya sekarang sudah tua, tapi harapan saya anak saya bisa mengerti dan melaksanakan perintah agama. Cara saya sebagai orang tua cuma bisa mengingatkan anak saya untuk shalat, mengaji dan juga cara bersopan santun yang baik, dan menghormati orang tua. Saya menyekolahkan anak saya di MIN agar mendapatkan pembelajaran agama yang lebih, saya juga menitipkan anak saya di tempat pengajian. Jika anak saya berbuat salah, saya menegurkan akan tetapi jika itu berlebihan saya akan menjewernya. Masalah saya dalam memberikan pendidikan keagamaan kepada anak yaitu pertama karena saya jarang dirumah jadi saya kurang bisa mengawasi anak-anak dan juga anak saya sering melawan, dan tidak mau mendengarkan teguran saya, anak saya menirukan perilaku yang buruk dari temen padahal saya sudah memberi tahu jika yang buruk jangan ditiru" (Wawancara, 1 Januari 2020)

Pendidikan anak dalam keluarga yang paling utama adalah mengajarkan sopan santun. Karena sopan santun merupakan sesuatu yang mahal. Apalagi untuk saat ini, semakin lama sopan santun yang dimiliki anak semakin berkurang. Mengajarkan sopan santun pada anak harus dimulai sejak dini agar tertanam kuat dalam benak si anak. Orang tua bisa mengajarkan sopan santun di saat anak mulai berusia 
masih kecil dan itu harus dimulai dari orang tuanya sendiri, jadi saat anak berusia kecil harus dibiasakan melihat orang tuanya bersikap baik dan santun. Sebagaimana yang telah diajarkan oleh bapak udin bahwa: "Dirumah saya kurang menyiapkan buku-buku jadi anak saya belajar agama dari buku-buku pembelajaran keagamaan disekolah. Saya juga sudah mengajarkan sopan santun, mengingatkan anak untuk mengaji, shalat serta berpuasa. Jika anak melakukan kesalahan maka saya akan menegurnya. Saya menyuruh pergi mengaji setiap sore, terkadang anak pergi, terkadang anak bermalas-masan dirumah. Begitupun shalat terkadang mau terkadang tidak mau saya juga maembatasi semua aktifitas atau pergaulan anak-anak agar terhindar dari hal buruk. Berusaha memberi tahu apa yang baik untuk dilakukan dana apa yang tidak boleh dilakukan" (Wawancara, 1 Januari 2020)

Metode merupakan salah satu sarana penting dalam proses mendidik seorang anak melalui proses pendidikan agama islam yang harus dikaji dan dikembangkan. Sejalan dengan tuntutan perkembangan jiwa anak agar mampu membawa dirinya dalam aneka kompetisi kehidupan modern. Salah satu aspek yang seharusnya mendapat perhatian utama oleh setiap orangtua adalah mengenai fasilitas pengajaran pendidikan agama islam. Sarana pendidikan keagamaan umumnya mencakup semua fasilitas yang secara langsung dipergunakan dan menunjang proses pendidikan, didalam pendidikan keagamaanpun membutuhkan sarana dan prasarana untuk memudahkan anak-anak didalam mendapatkan suatu ilmu keagamaan.

Hal yang disampaikan oleh bapak Sawal, bahwa : "saya kurang menyiapkan buku-buku pendidikan keagamaan untuk anak-anak, akan tetapi saya membeli tab atau handphone agar ia bisa belajar pengetahuan agama dari sana, karena saya jarang dirumah. Saya menitipkan anak-anak untuk belajar mengaji di tempat ngaji, kalo dirumah anak-anak jarang mengaji. Kalo pengetahuan agama saya kurang paham, tetapi kalo mengenai sopan santun atau akhlak yang baik pasti saya terapkan ke anak saya. Karena pasti setiap orang tua tidak mau anak-anaknya berperilaku buruk" (Wawancara, 2 Januari 2020)

Lain lagi yang disampaikan oleh Bapak Endang dan Buk Yeyen, bahwa : "Saya mengajarkan anak saya untuk shalat, untuk mengaji. saya mengajak anak untuk shalat serta mengajarkan anak berpuasa. Saya selalu mengawasi anak saya didalam pergaulannya 
seperti jangan bermain terlalu jauh atau jangan bermain dengan teman yang nakal. Saya menitipkan anak saya untuk mengaji. Saya memberikan buku tuntunan shalat, bacaan ayat pendek dirumah. Saya tidak terlalu memaksakan anak jika mau lakukan, jika tidak ya dibiarkan dulu" (Wawancara, 2 Januari 2020)

Berkelahi merupakan suatu perbuatan yang tercela atau seperti yang selalu didengar berkelahi itu adalah suatu tindakan yang buruk dan harus dihindari karena dengan berkelahi akan merusak bahkan menghancurkan silaturahmi antar tiap muslim. Berkelahi juga akan membuat timbulnya permusuhan dan rasa saling dendam dan membenci. Selanjutnya mengenai akhlak anaknya, Bapak Nuar mengatakan bahwa : "Saya menyuruh anak saya untuk menuntut ilmu dengan baik, dan bergaul dengan baik dimasyarakat. Saya telah membiasakan anak-anak untuk shalat, mengaji, berpuasa. Saya mengajarkan sopan santun kepada anak dengan menghormati orang yang lebih tua dan tidak melawan. Cara saya menasehati anak jika ia melakukan kesalahan yaitu dengan menasehatinya tapi jika sudah kelewatan maka harus saya pukul" (Wawancara, 2 Januari 2020)

Berdasarkan hasil wawancara peneliti dengan beberapa orangtua penambang emas dikelurahan kampung jawa dapat diketahui bahwa peran orangtua penambang emas dalam menanamkan pendidikan akhlak kepada anaknya berbeda-beda tergantung dengan pemahaman ilmu agama orangtua. Orangtua juga tidak sepenuhnya berperan aktif menjadikan keluarga sebagai madrasah utama untuk anak-anaknya, karena orangtua yang sibuk bekerja diluar. Akan tetapi orangtuanya berusaha mengajarkan perilaku yang baik untuk anakanaknya walaupun orangtua penambang emas tidak selalu dirumah. Ada juga orangtuanya telah berperan akan tetapi anak-anaknya sendiri yang lebih terpengaruh oleh lingkungan diluar dan sering berkelahi bahkan melawan kepada orangtuanya.

Orang tua dan keluarga yang merupakan madrasah pertama dalam kehidupan anak. Seorang anak menjalankan hampir seluruh kehidupannya dilingkungan keluarga. Oleh krena itu keluarga sangat bertanggung jawab untuk mengajari anak tentang berbagai perilaku Islami dan juga nilai-nilai pendidikan sosial yang baik bagi anak. Pendidikan Akhlak merupakan pendidikan yang paling penting dan paling pokok yang merupakan pondasi dasar dalam ajaran Islam. Ini sangat penting diajarkan karena untuk menentukan cara berperilaku dan bersikap, maka dari itu sangat penting diajarkan pada anak sejak 
usia dini. Ini untuk membentuk kepribadian muslim yang baik ke depannya. Oleh karena itu harus diterapkan pada anak, contohnya seperti bagaimana adab makan yang baik, adab berteman, sopan santun kepada orangtua, menghormati yang lebih tua, menyayangi yang lebih muda dan lain sebagainya.

Dalam menanamkan akhlak yang baik kepada anaknya, seorang orangtua memiliki peran dan tugas tersendiri yaitu membimbing serta mengarahkan anak-anaknya dari kecil supaya anak-anak tersebut dapat menirukan contoh berakhlak yang baik dan agar anak semakin lama semakin terbiasa untu berakhlak yang baik serta tidak mniru perilaku yang buruk. Keluarga merupakan lembaga pendidikan tertua, bersifat informal yang pertama dan utama dialami oleh anak serta lembaga pendidikan yang bersifat kodrati orang tua bertanggung jawab memelihara, merawat, melindungi dan mendidik anak agar tumbuh dan berkembang dengan baik.

Setiap keluarga sudah pasti tidak ingin memiliki anak yang berkelakuan buruk atau memiliki anak yang berakhlak mazmumah namun terkadang anak berakhlak demikian karena dipengaruhi oleh berbagai factor. Untuk menyikapi kelakuan anak yang sedemikian rupa maka orangtua harus melakukan berbagai usaha dalam mengatasi kelakuan anak tersebut. Peran orangtua di kelurahan kampung jawa terhadap anaknya dilingkungan penambang emas ini yaitu orangtua telah memberikan sedikit perhatian kepada anaknya terhadap pentingnya mempelajari pendidikan agama islam akan tetapi untuk orangtua yang memiliki pendidikan rendah maka ia tidak mengetahui seberapa pentinya pendidikan keagamaan ini untuk anakanaknya.

Orang tua pasti ingin memiliki harapan yang baik untuk semua anak-anaknya agar dapat berperilaku dengan baik sesuai yang diperintahkan oleh ajaran agama namun peran yang diberikan orangtua penambang emas ini berbeda-beda, untuk orangtua yang memiliki ilmu agama maka ia akan mengajari anaknya ilmu agama ketika orangtua tersebut dirumah. Orangtua penambang emas ini tidak dapat sepenuhnya berperan untuk menanamkan ilmu agama pada anak-anaknya dikarenakan orang tuanya sendiri sibuk dengan pekerjaanya. Dari sini pembagian waktu untuk anak kurang akhirnya menjadikan keadaan menjadi beku. Seharusnya orang tua juga bisa mengatur waktu dan dapat memperhatikan anaknya bukan hanya mencari nafkah dan kurang mengawasi keadaan pendidikan akhlak 
anaknya.

Namun bagi orangtua yang memiliki ilmu agama yang rendah lebih menyerahkan pendidikan agamanya kepada lembaga keagamaan yang ada. Ada juga sebagaian orangtua yang bekerja sebagai penambang emas ini telah berperan melaksakan tugasnya sebagai madrasah pertama untuk anak-anaknya, akan tetapi anak-anaknya yang susah diatur dan tidak mendengarkan perkataan orangtuanya, karena masih ada anak-anak yang suka melawan kepada orangtuanya padahal orangtuanya sudah menasehati anaknya.

\section{Problematika Peran Orang Tua Dalam Menanamkan Pendidikan Agama Islam Khususnya Pendidikan Akhlak Pada Anak Di Kelurahan Kampung Jawa}

Berdasarkan hasil wawancara peneliti dengan beberapa orangtua penambang emas dikelurahan kampung jawa dapat diketahui bahwa problematika orangtua penambang emas dalam menanamkan pendidikan agama islam anaknya yaitu terkendala oleh kesibukan orangtua yang membuat anak-anak kurang terkontrol untuk berprilaku yang sesuai ajaran islam. Anak susah diatur serta susah dinasehati, hal ini yang membuat anak-anak sering mengulangi kesalahan yang pernah ia lakukan. Anak juga lebih terpengaruh oleh lingkungan diluar ketika ia bergaul dengan teman-temannya serta anak sering berkelahi bahkan ada yang melawan kepada orangtuanya.

a. Faktor internal

Faktor internal merupakan sebagai suatu hambatan yang diakibatkan oleh faktor dari dalam keluarga, dalam hal ini orang tua. Kesibukan orang tua dalam bekerja diluar dan tidak sepenuhnya bisa berkumpul dengan keluarga sehingga anak sehari-hari kurang terkontrol dari pengawasan orang tua, hal ini membuat terhambatnya anak-anak dalam mendapatkan pemahaman agama mengenai akhlak yang baik.

Padahal bimbingan dan pengawasan dari orang tua sangat diperlukan anak dalam membentuk akhlaknya. Walaupun orang tua kurang dapat mengawasi secara langsung aktivitas anak, namun sebagai orang tua yang bertanggung jawab, hal yang dilakukan ialah dapat mengontrol anak-anak dengan menitipkan anak-anak di TPA atau pengajian anak-anak.

b. Faktor eksternal

Fakor eksternal yaitu suatu hambatan yang dihadapi oleh 
orang tua karena anak susah di atur dan anak suka melawan serta tidak mau mendengarkan perkatan orang tua atau selalu mengulangi kesalahan yang pernah diperbuat. seseorangpun dapat terpengaruh oleh lingkungan. Apabila seseorang berada di suatu lingkungan yang baik, seseorang akan dapat terbawa oleh lingkungan tersebut. Begitupun sebaliknya jika seseorang berada didalam lingkungan yang buruk, maka hal buruk juga yang akan seseorang dapatkan. Orangtua di Kelurahan Kampung Jawa ini sangat prihatin atas perkembangan zaman yang semakin modern. Pada saat ini orang tua dituntut untuk bisa mendidik, membimbing, memberikan arahan yang sesuai dengan norma yang berlaku, namun disatu sisi pesatnya arus globalisasi lewat media seperti tayangan $\mathrm{TV}$, handphone sangat kuat mempengaruhi jiwa anak.

Disinilah orang tua dituntut untuk memberikan pendidikan akhlak yang baik agar anak tidak terjerumus oleh arus globalisasi yang berdampak negative bagi anak. Orang tua yang bekerja sebagai penambang emas di Kelurahan Kampung Jawa dalam menanamkan pendidikan agama khususnya pendidikan akhlak pada anak terhambat oleh pengaruh lingkungan sekitar yaitu pengaruh teman bermain dilingkungannya, anak-anak sering mengikuti atau meniru temanteman sekitar dengan hal yang tidak baik seperti berkata kotor, melawan kepada orang tua serta berkelahi sesamanya. Didalam perkembangan zama yang semakin modern anak-anak juga terpengaruh oleh media seperti tayangan TV, Handphone. Anak-anak sering menonton TV sampai lupa waktu dan juga sering tidak mendengarkan perkataan atau nasehat orang tua jika mereka sedang menonton TV. Anak-anak juga senang bermain handphone, dan lebih senang memainkan handphone daripada membantu orang tuanya. Perkembangan perilaku anak sangat dipengaruhi oleh proses perlakuan atau bimbingan orang tua terhadap anak. Terutama dalam mencontohkan suatu hal yang baik. Orang tua harus mengarahkan anak agar dapat beprilaku yang baik dan memiliki akhlak yang baik. Agar pemahaman keagamaan anak semakin meningkat serta anak bisa memiliki akhal yang baik.

\section{Simpulan}

Kondisi pedidikan agama islam pada anak penambang emas yaitu pemahaman keagamaannya bisa dikatakan lumayan untuk anak- 
anaknya walaupun dominan orang tua nya kurang mengerti mengenai perintah agama. Akan tetapi orang tuanya tetap mengajarkan pengetahuan pendidikan agama islam pada anak-anaknya sesuai pengetahuan orang tuanya, karena orang tuanya lebih memfokuskan anak-anak ke sekolah dan pengajian. Jadi orang tuanya tidak khawatir mengenai hal tersebut.

Peran orangtua penambang emas dalam menanamkan pendidikan akhlak kepada anaknya berbeda-beda tergantung dengan pemahaman ilmu agama orangtua. Orangtua juga tidak sepenuhnya berperan aktif menjadikan keluarga sebagai madrasah utama untuk anak-anaknya, karena orangtua yang sibuk bekerja diluar. Akan tetapi orangtuanya berusaha mengajarkan perilaku yang baik untuk anakanaknya walaupun orangtua penambang emas tidak selalu dirumah. Ada juga orangtuanya telah berperan akan tetapi anak-anaknya sendiri yang lebih terpengaruh oleh lingkungan diluar dan sering berkelahi bahkan melawan kepada orangtuanya.

Problematika yang dihadapi orangtua penambang emas di Kelurahan Kampung Jawa Kecamatan Lebong utara Kabupaten Lebong dalam menanamkan pendidikan agama islam pada anaknya terdiri dari faktor internal dan faktor ekternal. Faktor internal yang menjadi problematika orangtua penambang emas dalam menanamkan pendidikan agama islam anaknya yaitu terkendala oleh orangtua yang sibuk bekerja yang membuat anak-anak kurang terkontrol untuk berprilaku baik yang sesuai ajaran islam. Faktor ekternal yang menjadi problematika orangtua penambang emas dalam menanamkan pendidikan agama islam pada anaknya yaitu terkendala oleh anak susah diatur serta susah dinasehati, hal ini yang membuat anak-anak sering mengulangi kesalahan yang pernah ia lakukan. Anak juga lebih terpengaruh oleh lingkungan diluar ketika ia bergaul dengan temantemannya serta anak sering berkelahi bahkan ada yang melawan kepada orangtuanya.

Saran yang harus diperhatikan orangtua dan lembaga yaitu kepada orangtua hendaknya selalu membimbing dan mengarahkan anak untuk meningkatkan pendidikan agama islam sehingga dapat menjadi contoh yang baik bagi anak-anak karena orangtualah yang menjadi madrasah utama bagi anak, agar anak dapat berprilaku yang baik sesuai ajaran agama islam. Serta orangtua diharapkan untuk selalu mengikuti pengajaran keagamaan agar lebih dapat atau lebih memungkinkan dalam melakukan perannya untuk membimbing anak- 
anaknya. Untuk lembaga keagaamaan agar lebih memperhatikan pendidikan agama baik bekal untuk anak-anak maupun untuk orangtua.

\section{DAFTAR PUSTAKA}

Abdul Majid, 2012, Belajar dan Pembelajaran Pendidikan Agama Islam, Bandung: Remaja Rosdakarya.

Arifin, 2008, Ilmu Pendidikan Islam, Jakarta: Bumi Aksara.

B. Hurlock Ellizabeth, 1956, Psikologi Perkembangan; Suatu Pendekatan Sepanjang Rentang Kehidupan, Jakarta : Erlangga.

Darajat, Zakiyah, 1976, Perawatan Jiwa untuk Anak-anak, Jakarta : Bulan Bintang.

Departemen Agama RI, 2005, Al-Qur'an dan Terjemahan, Bandung: CV Jumanatul 'Ali-Art.

Diadha, Rahminur, 2015, Keterlibatan Orang Tua Dalam Pendidikan Anak Usia Dini Di Taman Kanak-Kanak, Edusentris 2, no. 1.

Edi, Wawancara dengan Warga, Kelurahan Kampung Jawa, 15 November 2019

Endang, Wawancara dengan Orangtua Penambang Emas di Kelurahan Kampung Jawa, 2 Januari 2020

Fitri, A. Z. (2016). Keluarga Sebagai Lembaga Pertama Pendidikan Islam. Jurnal Pendidikan Islam UIN Sunan Gunung Djati, 27(1), 21-34.

Fratama, E. R., Warsah, I., \& Karolina, A. (2019). Pendidikan Toleransi Masyarakat Multikultural Desa Suro Bali (Doctoral dissertation, Institut Agama Islam Negeri Curup).

Hempiyu Hendro, Wawancara dengan Orangtua Penambang Emas di Kelurahan Kampung Jawa, 1 Januari 2020 
20 Wilyam, Beni, dkk, Peran Orangtua Penambang Emas,....

Hyoscyamina, D. E. (2011). Peran keluarga dalam membangun karakter anak. Jurnal Psikologi, 10(2), 144-152.

Lexy, Meleong, 2006, Metodologi Penelitian, Bandung: Remaja Rosdakarya.

Mulia, A. (2019). Pendidikan Akhlak Anak dalam Keluarga Nelayan di Desa Dahari Selebar Kecamatan Talawi Kabupaten Batu Bara (Doctoral dissertation, Universitas Islam Negeri Sumatera Utara).

Nana Sudjana, 2004, Penelitian dan Penilaian Pendidikan, Bandung: Sinar Baru Algensindo.Nur Uhbiyati, 2005, Ilmu Pendidikan Islam, Bandung: Pustaka Setia.

Novi, Wawancara dengan Orangtua Penambang Emas di Kelurahan Kampung Jawa, 20 Desember 2019

Nuar, Wawancara dengan Orangtua Penambang Emas di Kelurahan Kampung Jawa, 2 Januari 2020

Primer, Wawancara dengan Orangtua Penambang Emas di Kelurahan Kampung Jawa, 1 Januari 2020

Riduwan, 2012, Belajar Mudah Penelitian Untuk Guru dan Peneliti Pemula, Bandung: Alfabeta.

Samsir, Wawancara dengan Tokoh Agama di Kelurahan Kampung Jawa, 01 Maret 2020

Sawal, Wawancara dengan Orangtua Penambang Emas di Kelurahan Kampung Jawa, 2 Januari 2020

Singgih D, 1995, Gunarsa. Psikolog Praktis Anak, Remaja dan Keluarga. Jakarta. PT. BPK Gunung Mulia.

Sudiyono, 2009, Ilmu Pendidikan Islam Jilid 1, Jakarta: Rineka Cipta. 
Sugiyono, 2011, Metode Penelitian Pendidikan, Pendekatan Kualitatif, Kuantitatif dan $R \& D$, Bandung: Alfabeta.

Sugiyono, 2014, Memahami Penelitian Kualitatif, Bandung: Alfabeta.

Sujiarti, Wawancara dengan Tokoh Agama di Kelurahan Kampung Jawa, 29 Desember 2019

Sumardi Subrata, Metodologi Penelitian, Jakarta: Raja Grafindo Persada

Sutra, N. (2017). Peran Orang Tua Dalam Pembinaan Akhlak Anak di Desa Wonua Morini Kecamatan Palangga Kabupaten Konawe Selatan” (Doctoral dissertation, IAIN KENDARI).

Udin, Wawancara dengan Orangtua Penambang Emas di Kelurahan Kampung Jawa, 1 Januari 2020

Ujang, Wawancara dengan Orangtua Penambang Emas di Kelurahan Kampung Jawa, 1 Januari 2020

Wen Doni, Wawancara dengan Orangtua Penambang Emas di Kelurahan Kampung Jawa, 1 Januari 2020 